\title{
Transduction of $\mathrm{Ca}^{2+}$ signals upon fertilization of eggs; identification of an S-100 protein as a major $\mathrm{Ca}^{2+}$-binding protein
}

\author{
Vasily V. Ivanenkov ${ }^{\text {b }}$, Volker Gerke ${ }^{\text {a }}$, Andrei A. Minin ${ }^{\text {b }}$, Uwe Plessmann ${ }^{a}$ \\ and Klaus Weber ${ }^{\text {a }}$ \\ ${ }^{a}$ Max Planck Institute for Biophysical Chemistry, Department of Biochemistry, Goettingen, Germany and ${ }^{b}$ Institute of Developmental \\ Biology, Russian Academy of Sciences, Moscow, Russia
}

(Received 16 March 1992; accepted 1 April 1993)

A transient increase in the level of free cytosolic $\mathrm{Ca}^{2+}$ is observed upon fertilization of the eggs of many species and is thought to represent a key event in the initiation of development. To identify components in the egg which could be involved in mediating such $\mathrm{Ca}^{2+}$ signals we searched for $\mathrm{Ca}^{2+}$-binding proteins in eggs of the fresh-water fish Misgurnus fossilis (loach). We show that loach eggs contain two major $\mathrm{Ca}^{2+}$-binding proteins which can be purified through their $\mathrm{Ca}^{2+}$-dependent interaction with a hydrophobic matrix. Protein sequencing revealed that the larger 18 $\mathrm{kDa}$ protein is calmodulin, while the smaller polypeptide of $10 \mathrm{kDa}$ is a member of the $\mathrm{S}-100$ protein family. This is the first report of the presence of an S-100 protein in vertebrate eggs and shows that this protein is found in two fold higher concentration than calmodulin. Since the $10 \mathrm{kDa}$ protein shares $68 \%$ sequence identity with $\mathrm{S}-100 \alpha$ from bovine brain, it can be considered as the loach homologue of mammalian S-100 $\alpha$. During early embryonic development, de novo protein synthesis of calmodulin is observed at the earliest stages analyzed (mid-blastula), while de novo protein synthesis of the S-100 $\alpha$ homologue begins with the mid-gastrula stage. Although both proteins are likely to serve as mediators of $\mathrm{Ca}^{2+}$ signals and/or as $\mathrm{Ca}^{2+}$-buffers in the egg, the tighter regulation of the synthesis of the S-100 protein as compared to calmodulin argues for an additional and probably more specialized function of the $S-100 \alpha$ homologue in later embryogenesis, which could be restricted to certain cell types.

Fertilization; $\mathrm{Ca}^{2+}$-binding protein; $\mathrm{S}-100$ protein

\section{Introduction}

Fertilization of the eggs of many species is accompanied by a transient increase in the level of free $\mathrm{Ca}^{2+}$ in the cytoplasm which is thought to trigger development (for review see Jaffe, 1985). In fish eggs, a transient rise in the concentration of free $\mathrm{Ca}^{2+}$ starts at the site of sperm entry (animal pole), transverses the egg as a narrow band, and vanishes at the antipode (Gilkey et al., 1978; Yoshimoto et al., 1986; Iwamatsu et al., 1988; Hiramoto et al., 1989). The peak value of the $\mathrm{Ca}^{2+}$ transient in the cortical cytosplasm was estimated to be as high as $30 \mu \mathrm{M}$ (Gilkey et al., 1978). The $\mathrm{Ca}^{2+}$ wave

Correspondence to: V. Gerke, Max Planck Institute for Biophysical Chemistry, Department of Biochemistry, P.O. Box 2841, W-3400 Goettingen, Germany. triggers exocytosis of cortical granules (Gilkey, 1983; Yoshimoto et al., 1986) and the assembly of the fertilization envelope (Schuel, 1985) and is also considered to be the sole cause for cell cycle resumption at fertilization (for review see Whitaker and Patel, 1990).

Although the significance of $\mathrm{Ca}^{2+}$ transients for the initiation of developmental processes in the egg is well documented, the molecular events underlying the egg's response to changes in the level of free $\mathrm{Ca}^{2+}$ concentrations are only poorly understood. While protein kinase $\mathrm{C}$ seems to play an important role in triggering development in amphibian and mammalian eggs (Bement and Capco, 1989; Endo et al., 1987), additional $\mathrm{Ca}^{2+}$-binding proteins are likely to be involved in the stimulus-response coupling in fertilized eggs from several other species, e.g. chordates (Ciapa et al., 1988). Due to their $\mathrm{Ca}^{2+}$-binding properties the so-called S-100 proteins, which so far have only been isolated 
from somatic cells or tissues, are candidates for mediating $\mathrm{Ca}^{2+}$ signals also in the egg. $\mathrm{S}-100$ proteins are members of a family of small dimeric polypeptides which are characterized by a twofold repetition of a helix-loop-helix structure involved in $\mathrm{Ca}^{2+}$-binding (for review see Hilt and Kligman, 1991; Donato, 1991). This so-called EF-hand is also found in other polypeptides which form, together with the S-100 like-proteins, the EF-hand superfamily of $\mathrm{Ca}^{2+}$-binding proteins. Typical members of the EF-hand family which are built from four consecutive EF-hands are calmodulin and troponin C (for review see Klee et al., 1980; Kretsinger, 1987; Persechini et al., 1989).

To date 12 members of the S-100 branch of the EF-hand superfamily have been identified. The two principal proteins of this $S-100$ family are $S-100 \alpha$ and $\mathrm{S}-100 \beta$, which were identified in bovine brain more than 20 years ago (Moore, 1965). S-100 $\alpha$ and S-100 $\beta$ share $57 \%$ sequence identity and form homo- as well as heterodimers (Isobe et al., 1977). Each polypeptide chain contains two $\mathrm{Ca}^{2+}$-binding sites. The higher affinity site (around $\mu \mathrm{M}$ ) is located in the C-terminal half of the molecule while the lower affinity site (around $\mathrm{mM}$ ) involves the N-terminal half (Kretsinger, 1980; Baudier and Gerard, 1983; Baudier and Cole, 1988; Becker et al., 1992). While the $\mathrm{Ca}^{2+}$-binding loop of the C-terminal EF-hand contains 12 amino acids and is similar in sequence to the corresponding loops in calmodulin and troponin $\mathrm{C}$, the N-terminal EF-hand loop of S-100 proteins comprises 14 instead of 12 residues. This feature is conserved in all S-100-like proteins and is probably the basis of the low affinity of the $\mathrm{N}$-terminal $\mathrm{Ca}^{2+}$-binding site. In addition to $\mathrm{S}-100 \alpha$ and S-100 $\beta$, other members of the S-100 family have been identified in recent years (for review see Hilt and Kligman, 1991).

Although the biological role of individual S-100 proteins is not known, putative cellular targets, which could be regulated by $\mathrm{S}-100$ proteins in a $\mathrm{Ca}^{2+}$-dependent manner, have been described. S-100 itself binds to cytoskeleton associated proteins, e.g. microtubule associated proteins and caldesmon, and to the glycolytic enzyme aldolase in the presence of $\mathrm{Ca}^{2+}$ (Baudier and Cole, 1988; Fujii et al., 1990; Zimmer and van Eldik, 1986). $\mathrm{A} \mathrm{Ca}^{2+}$-dependent interaction with another glycolytic enzyme, glyceraldehyde-3-phosphate dehydrogenase, has been described for calcyclin (Filipek et al., 1991). Calcyclin also interacts in a $\mathrm{Ca}^{2+}$-dependent manner with CAP-50, a newly identified member of the annexin family of $\mathrm{Ca}^{2+}$ and phospholipid binding proteins (Tokumitsu et al., 1992). However, the unambiguous identification of a cellular ligand has so far only been possible for p11, a member of the S-100 family which has suffered deletions and substitutions in both EF-hand loops and thus has lost the ability to bind $\mathrm{Ca}^{2+}$ (Gerke and Weber, 1985a; Glenney, 1986).
Both in vivo and in vitro p11 forms a tight heterotetrameric complex with annexin II and thereby regulates biochemical properties of this $\mathrm{Ca}^{2+} /$ phospholipid-binding protein (Gerke and Weber, 1984, 1985b; Powell and Glenney, 1987; Osborn et al., 1988; Drust and Creutz, 1988).

In contrast to calmodulin, which seems to be present in all eukaryotic cells, the individual S-100 proteins show a much more restricted and often cell-type specific expression pattern. However, an analysis of the expression patterns has so far been restricted to mammals, and very few data concerning the occurrence of S-100 proteins in other organisms have been obtained. To analyze the expression and possible function of $\mathrm{Ca}^{2+}$-binding proteins, in particular members of the S-100 family, in early stages of embryonic development and to extend our knowledge on the conservation of S-100 proteins we have analyzed $\mathrm{Ca}^{2+}$-binding proteins present in the fresh-water fish Misgurnus fossilis (loach). We show that loach eggs contain a highly conserved calmodulin and considerable amounts of a $\mathrm{Ca}^{2+}$-binding protein of $10 \mathrm{kDa}$, most likely the $\mathrm{S}-100 \alpha$ homologue. While calmodulin is expressed throughout embryonic development, the de novo synthesis of loach $\mathrm{S}-100 \alpha$ is not observed before the mid-gastrula stage, indicating a more specialized role for the S-100 protein in later stages of development.

\section{Results}

Identification and purification of $\mathrm{Ca}^{2+}$-binding proteins from loach eggs

To identify $\mathrm{Ca}^{2+}$-binding proteins which could serve as mediators of $\mathrm{Ca}^{2+}$ signals in the egg we chose loach eggs as a model system. These eggs provide several advantages. First, they can be obtained in quantities sufficient for biochemical analyses, e.g. protein fractionation. Second, the eggs can be fertilized artificially (Neyfakh, 1959) and thus provide a simple system to study the expression of $\mathrm{Ca}^{2+}$-binding proteins during embryonic development. Third, a characterization of the composition of $\mathrm{Ca}^{2+}$-binding proteins in a homogenous cell population (the egg) circumvents the potential complexity often observed in tissues consisting of different cell types.

Several $\mathrm{Ca}^{2+}$-binding proteins including those of the S-100 family share as a common biochemical property the $\mathrm{Ca}^{2+}$-dependent binding to hydrophobic matrices. We exploited this property to enrich for potential S-100 proteins present in the cytoplasm of loach eggs by $\mathrm{Ca}^{2+}$-dependent chromatography on phenyl-Sepharose. This approach led to the enrichment of two proteins with apparent molecular masses of $10 \mathrm{kDa}$ and $18 \mathrm{kDa}$ respectively, which bind to the phenyl-Sepharose in the presence of $\mathrm{Ca}^{2+}$ and are specifically 


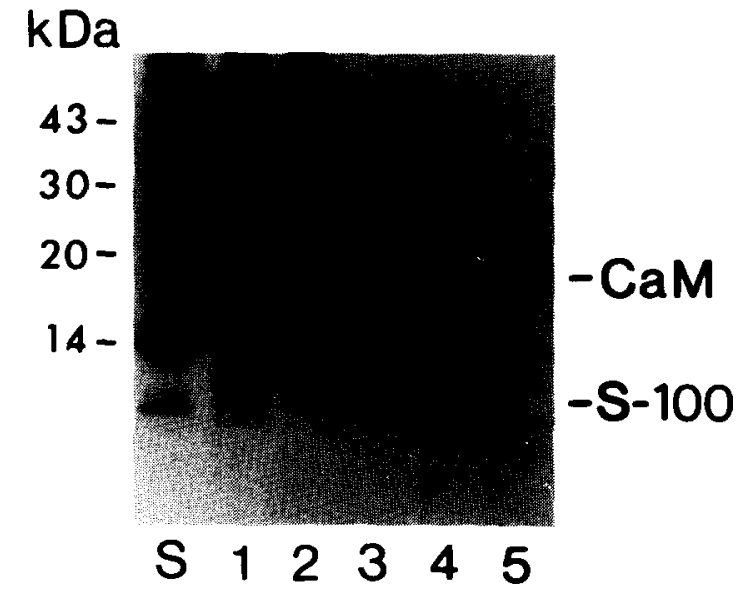

Fig. 1. Purification of calmodulin and an S-100 $\alpha$ homologue from loach eggs. The cytoplasm from unfertilized loach eggs (lane 1) was homogenized in the presence of $\mathrm{Ca}^{2+}$ and subjected to high speed centrifugation. The supernatant (lane 2) was applied to a phenylSepharose column in the presence of $\mathrm{Ca}^{2+}$. The material specifically eluted by the addition of EGTA was adjusted to $10 \mathrm{mM} \mathrm{CaCl}_{2}$ and passed over a second phenyl-Sepharose column. The EGTA eluate from this second column (lane 3) was fractionated on DEAE-Sepharose, leading to the purification of a $10 \mathrm{kDa}$ (S-100; lane 4) and an $18 \mathrm{kDa}$ protein (CaM; lane 5). Molecular weight markers separated in this tricine-SDS-16\% polyacrylamide gel (Schägger and von Jagow, 1987) are depicted in lane $S$.

eluted upon $\mathrm{Ca}^{2+}$-chelation by EGTA (Fig. 1). Both proteins can be subsequently separated by ion exchange chromatography on DEAE Sepharose. This protocol yields approximately $1.5 \mathrm{mg}$ of pure $10 \mathrm{kDa}$ and approximately $0.8 \mathrm{mg}$ of pure $18 \mathrm{kDa}$ protein from $40 \mathrm{ml}$ of egg cytoplasm.
The $10 \mathrm{kDa}$ and $18 \mathrm{kDa}$ proteins were further characterized by partial protein sequence analysis. Fragments obtained by $\mathrm{CNBr}$ cleavage were analyzed by automated gas phase sequencing. This approach yielded two sequences for the $18 \mathrm{kDa}$ protein $(\mathrm{CNBr} 1$ : TNLGEXLTDEEVDE; CNBr 2: IREA DIDGDGQVNYEEF). They are identical with residues 110 to 123 and residues 125 to 141 of human calmodulin (Fischer et al., 1988). The residue given as $\mathrm{X}$ in $\mathrm{CNBr} 1$ corresponds to the trimethyl-lysine established for several calmodulins at position 115. Thus the $18 \mathrm{kDa}$ protein is unambiguously identified as loach calmodulin. Three $\mathrm{CNBr}$-fragments covering together a total of 87 amino acid residues were obtained from the $10 \mathrm{kDa}$ protein. Their sequences showed a very strong homology to $\mathrm{Ca}^{2+}$-binding proteins of the S-100 family, in particular to bovine S-100 $\alpha$ (Figs. 2 and 3).

Complete amino acid sequence of the $S-100$ protein from loach eggs

To establish the relationship of the fish $10 \mathrm{kDa}$ protein to the different mammalian S-100 proteins, we determined the entire amino acid sequence. Direct $\mathrm{N}$-terminal sequencing after SDS-PAGE and blotting onto a polyvinyldifluoride membrane provided the $\mathrm{N}$ terminal 50 residues and connected $\mathrm{CNBr}$ fragments 1 and 2 (Fig. 2). Additional sequence information was obtained by in situ digestion of the $10 \mathrm{kDa}$ protein present on a membrane. Peptides released from the blot by endoproteinase Asp-N were separated by HPLC and fully sequenced. Peptides Asp 1-4 confirmed the $\mathrm{N}$-terminal 49 residues. Peptide 5 extended the se-
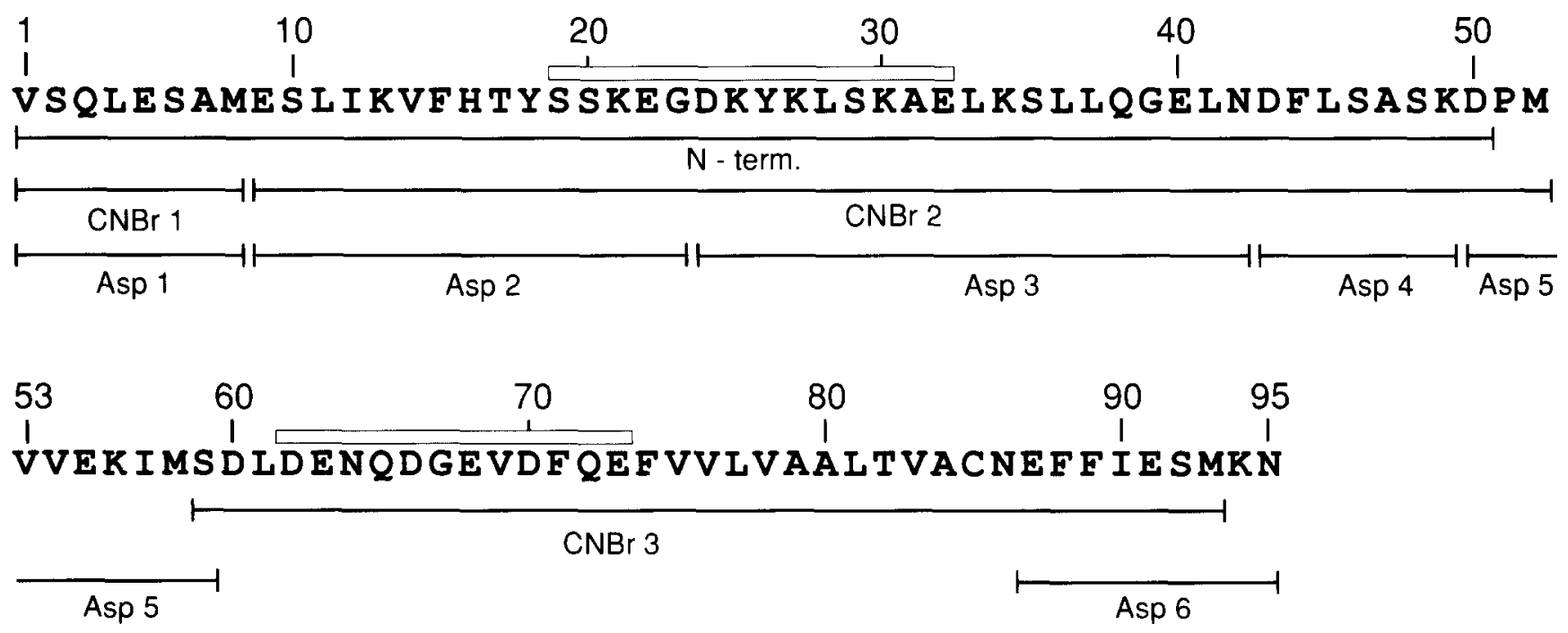

Fig. 2. Amino acid sequence of the $10 \mathrm{kDa}$ protein from loach eggs. Direct sequencing provided the $\mathrm{N}$-terminal 50 residues. The three $\mathrm{CNBr}$ fragments (CNBr 1-3) obtained by HPLC were completely sequenced. Peptides Asp 1-6 were obtained after digestion of the protein with endoproteinase Asp-N followed by HPLC (see Experimental Procedure). They were completely sequenced. Although the overlap between peptide Asp 5 and $\mathrm{CNBr}$ fragment 3 involves only serine 59, the high degree of sequence conservation and the lack of any length variability in this region of S-100 proteins (Fig. 3) allowed for the sequence proposed. The bars above the sequence indicate the positions of the predicted $\mathrm{Ca}^{2+}$-binding loops of the $\mathrm{N}$ - and C-terminal EF-hand. 
quence of $\mathrm{CNBr}$ fragment 2 by seven residues and provided a small overlap into $\mathrm{CNBr}$ fragment 3 . Peptide Asp 6 starts within $\mathrm{CNBr}$ fragment 3 and extends the sequence to the C-terminal end of the $10 \mathrm{kDa}$ protein. Asp-protease peptides from the region between residues 60 and 86 were not obtained, most likely because they are either very small or too hydrophobic to be released from the polyvinyldifluoride membrane. Although the overlap between peptide Asp 5 and $\mathrm{CNBr}$ fragment 3 involves only serine 59 and the prediction of a methionine at position 58 for the origin of $\mathrm{CNBr}-3$, we have not tried to obtain an independent overlap. The high degree of sequence conservation and the lack of length variability for $\mathrm{S}-100$ proteins in this region (Fig. 3) clearly allows for the sequence proposed. The sequence of the loach $10 \mathrm{kDa}$ protein shows two typical helix-loop-helix motifs likely to mediate the $\mathrm{Ca}^{2+}$-binding (Figs. 2, 3). The two EF-hands locate to the $\mathrm{N}$ - and the $\mathrm{C}$-terminal half of the molecule. As in mammalian S-100 proteins the $\mathrm{N}$ terminal EF-hand shows a longer loop (14 amino acids, residues 19-32) which is thought to reflect the corresponding low affinity $\mathrm{Ca}^{2+}$ site. The high affinity site in the C-terminal EF-hand is well conserved in all S-100 proteins including the loach protein (for review see Hilt and Kligman, 1991).
Comparison of the loach $10 \mathrm{kDa}$ protein sequence with the sequences of the different mammalian S- 100 proteins reveals a very close relationship (Fig. 3). Sequence identities range from $68 \%$ between the fish 10 $\mathrm{kDa}$ protein and bovine $\mathrm{S}-100 \alpha$ to $34 \%$ between the fish $10 \mathrm{kDa}$ protein and human MRP8. These sequence homologies are most pronounced in the region of the two EF-hand loops, indicating that these loops also function as $\mathrm{Ca}^{2+}$-binding sites in the loach protein. Due to the high degree of sequence similarity between the $10 \mathrm{kDa}$ protein from fish eggs and bovine $\mathrm{S}-100 \alpha$, the $10 \mathrm{kDa}$ protein can be considered to be the loach homologue of mammalian S-100 $\alpha$. Therefore we refer to this protein as loach $\mathrm{S}-100 \alpha$ throughout the rest of this text.

Expression of $S-100 \alpha$ and calmodulin during early embryonic development of the loach

Embryonic development of the loach Misgurnus fossilis can be studied following artificial fertilization of mature eggs (Neyfakh, 1959). Upon cultivation, embryos reach mid-blastula stage $7 \mathrm{~h}$ and mid-gastrula stage $14 \mathrm{~h}$ after fertilization. Hatching of loach larvae is observed approximately $50 \mathrm{~h}$ after fertilization. To analyze the expression of the two $\mathrm{Ca}^{2+}$-binding proteins during the different stages of development, we

\begin{tabular}{|c|c|}
\hline & 52 \\
\hline Mf $10 \mathrm{kDa}$ & VSQIESAMESLIKVFHTYSSKEGDKYKISKAEIKS L LGELNDFISASKDPM- \\
\hline bo $S-100 \alpha$ & 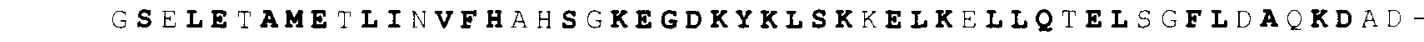 \\
\hline bo S-100及 & 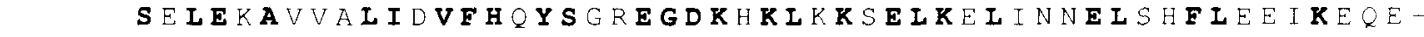 \\
\hline bo S-100L & 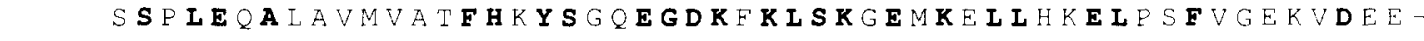 \\
\hline$h u \mathrm{~S}-100 \mathrm{P}$ & 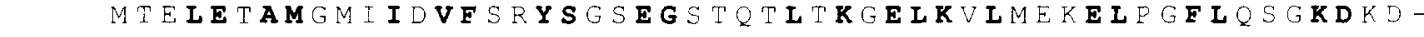 \\
\hline po pll & 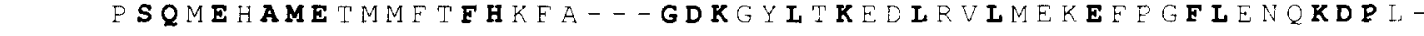 \\
\hline$h$ 2A9 & 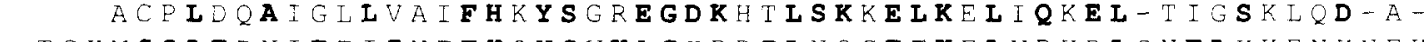 \\
\hline hu MRP 14 & 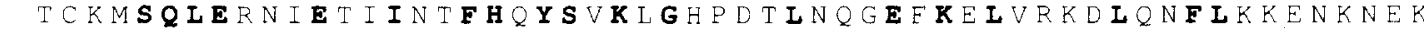 \\
\hline po S-100C & 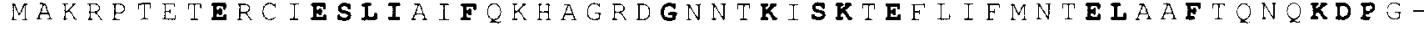 \\
\hline & 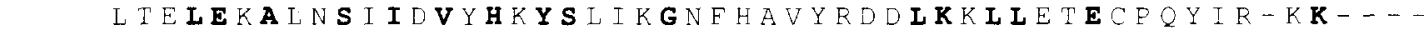 \\
\hline
\end{tabular}

Mf $10 \mathrm{kDa}$

bo $\mathrm{S}-100 \alpha$

bo $\mathrm{S}-100 \beta$

mu $18 \mathrm{~A} 2$

bo S-100L

hu S-100P

po pl1

rh Calgizzarin

hu $2 \mathrm{~A} 9$

hu MRP 14

po $\mathrm{S}-100 \mathrm{C}$

hu MRP 8
5.3

\section{5}

VVEKIMSDLDENQDGEVDFQEEVVLVAALTVACNEFFIESM-KN

AVDKVMKELDEDGDGEVDFOEYVVLVAALTVACNNFFWENS

VVDKVMETLDSDGDGECDF Q E F M A V AMITTACHEFFEHE

AEQKVMSNLDSNRDNEVDFQEYCVELSCI AMMCNEFFEGCFDKEPRKK

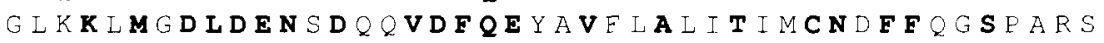

A VDKLLKDLDANGDAQVDFSEFIVFVAAITSACHKYFEKAGLK

A VDKIMKDIDQCRDGKVGFQSFFSIIAGLTIACNDYFVVHM-KQKGKK

VLDRMMKLLDLNSDGQLDF Q E F LNLIGGLAVACHESTVKAAP Q Q RE

EIARLMEDLDRNKDQEVNFQEYVTFLGALALIYNEALKG

VIEH I M E D L D T N A D Q L S E E F IMLMARLTWASHEKMHEGDEGPHHHKPGLGGTP

VLDRMMKKLDLDSDGQLDFQEFLNLIGGLAI ACHDSFIKSTQK

GADVWFKELDINTDGAVNFQEFLILVIKMGVAAHKKSHEESH KE

Fig. 3. Sequence comparison of fish S-100 $\alpha$ with other proteins of the S-100 family. The amino acid sequence of the S-100 $\alpha$ homologue from the loach (Mf $10 \mathrm{kDa}$ ) is compared to the sequences of bovine S-100 $\alpha$ (Isobe and Okuyama, 1981), bovine S-100 $\beta$ (Isobe and Okuyama, 1978), murine 18A2 (Jackson-Grusby et al., 1987), bovine S-100L (Glenney et al., 1989), human S-100P (Becker et al., 1992), porcine p11 (Gerke and Weber, 1985a), rabbit calgizzarin (Watanabe et al., 1991), human 2A9 (Calabretta et al., 1986), human MRP 14 and MRP 8 (Odink et al., 1987), and porcine S-100C (Ohta et al., 1991). Amino acids identical to the equivalent position in Mf S-100 $\alpha$ are given in bold letters. Predicted $\mathrm{Ca}^{2+}$-binding loops of the $\mathrm{N}$ - and $\mathrm{C}$-terminal EF-hand are marked by horizontal lines. 


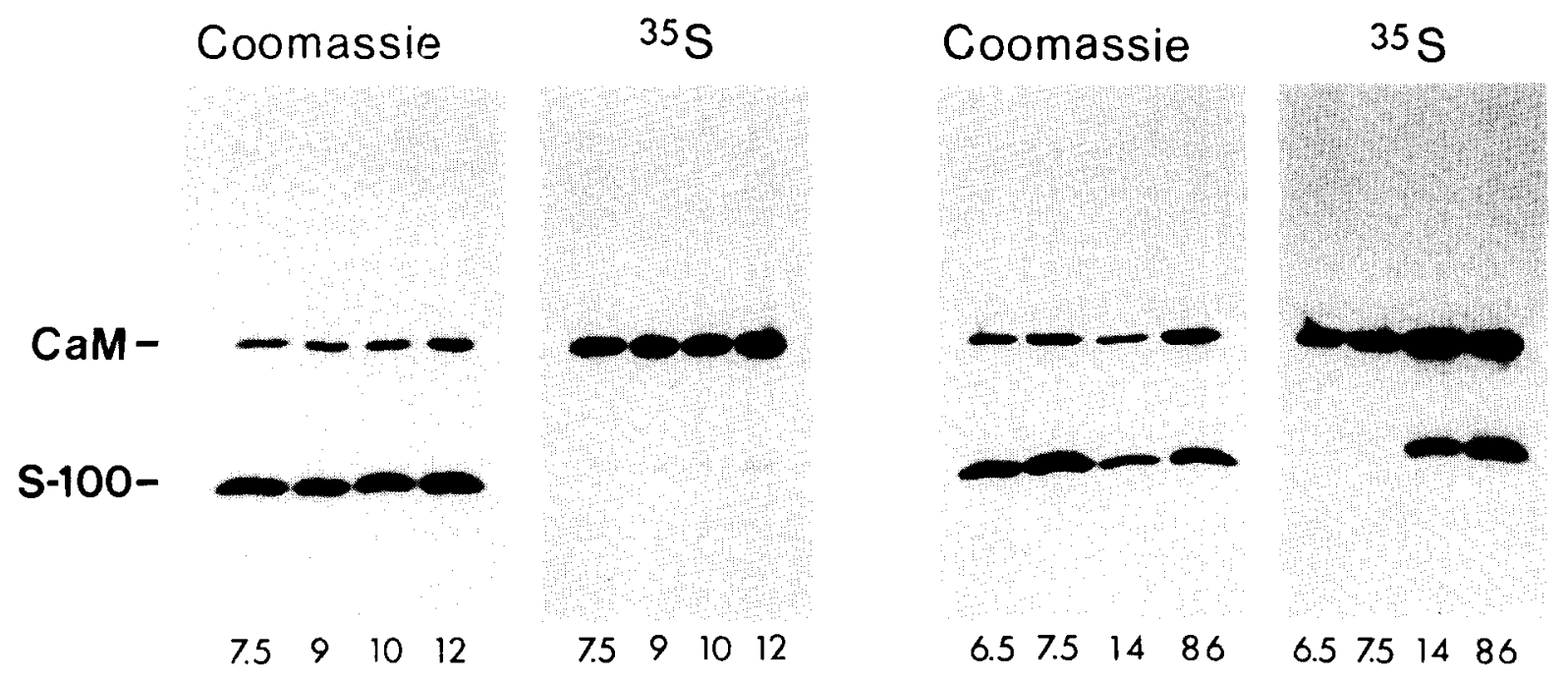

Fig. 4. Expression of the S-100 $\alpha$ homologue and calmodulin during early embryonic development of the loach. Loach embryos were labelled with $\left[{ }^{35}\right.$ S $]$ methionine $6.5,7.5,9,10,12,14$ or $86 \mathrm{~h}$ after fertilization (for labelling times see Experimental Procedures). Subsequently, the S-100 $\alpha$ homologue and calmodulin were purified by phenyl-Sepharose chromatography and analyzed in tricine-SDS-16\% polyacrylamide gels. The gels were stained with Coomassie blue and then processed for fluorography to visualize ${ }^{35} \mathrm{~S}$-labelled polypeptides $\left({ }^{35} \mathrm{~S}\right)$. Results of two different experiments are shown. One experiment (left side) covers the times from $7.5 \mathrm{~h}$ to $12 \mathrm{~h}$. The other experiment (right side) spans the times from 6.5 $\mathrm{h}$ to $86 \mathrm{~h}$. Although both proteins are present as maternal pool in the eggs, they differ in the timing of new biosynthesis. Note that calmodulin is already newly synthesized (see ${ }^{35} \mathrm{~S}$ label) at mid-blastula stage $(6.5 \mathrm{~h}$ after fertilization) while new synthesis of the S-100 $\alpha$ homologue is not observed before mid-gastrula stage ( $14 \mathrm{~h}$ after fertilization).

performed a series of isotopic labeling experiments. The differently staged embryos were separated from the yolk and incubated in $\left[{ }^{35}\right.$ S $]$ methionine-containing medium for $75 \mathrm{~min}$. Extracts were subjected to the purification of calmodulin and S- $100 \alpha$ by phenyl-Sepharose chromatography (described above). $\mathrm{Ca}^{2+}$-binding proteins purified from the embryos at different stages of development were analyzed by SDS-PAGE, stained with Coomassie blue and analyzed by fluorography to visualize ${ }^{35} \mathrm{~S}$-labelled polypeptides (Fig. 4). This allowed us to distinguish between total $\mathrm{Ca}^{2+}$-binding proteins present (Coomassie stain) and $\mathrm{Ca}^{2+}$-binding proteins newly synthesized at a certain developmental stage (fluorography).

Loach S-100 $\alpha$ and calmodulin are present in unfertilized eggs (Fig. 1 and above) as well as in all embryonic stages analyzed (Fig. 4). The two $\mathrm{Ca}^{2+}$-binding proteins differ however during embryogenesis in the timing of new synthesis as measured by incorporation of $\left[{ }^{35} \mathrm{~S}\right]$ methionine into the purified products. While calmodulin synthesis is already observed at mid-blastula stage, with no earlier time point analyzed, synthesis of the S-100 $\alpha$ homologue becomes apparent only at midgastrula (Fig. 4). Thus the S- $100 \alpha$ of early embryos reflects the maternal pool already documented in the unfertilized egg (Fig. 1). Although calmodulin is already synthesized at the earliest embryonic stages analyzed (Fig. 4), a substantial fraction of the total embryonic calmodulin still reflects the calmodulin store of the unfertilized egg. This is evident from a comparison of the amounts of S-100 $\alpha$ and calmodulin purified from unfertilized eggs and early, e.g. mid-blastula, embryos, respectively.

\section{Discussion}

By using $\mathrm{Ca}^{2+}$-dependent affinity chromatography on phenyl-Sepharose we have purified two $\mathrm{Ca}^{2+}$-binding proteins from cytoplasmic extracts of unfertilized loach eggs, which are candidates for mediators of $\mathrm{Ca}^{2+}$ signals occurring upon fertilization. Sequence analysis established that both proteins belong to the EF-hand family of $\mathrm{Ca}^{2+}$-modulated proteins. Calmodulin, a ubiquitous $\mathrm{Ca}^{2+}$-binding protein with a fourfold repetition of the EF-hand structure, is highly conserved among species (Marshak et al., 1984; Babu et al., 1985; Davis et al., 1986). This is also illustrated by the fact that peptides obtained from the loach calmodulin are identical in sequence ( 31 out of 31 residues) to the corresponding region in human calmodulin. The other $\mathrm{Ca}^{2+}$-binding protein in loach eggs has a molecular mass of $10 \mathrm{kDa}$ and contains two EF-hands. The sequence of the $10 \mathrm{kDa}$ protein clearly demonstrates that it belongs to the S-100 branch of the EF-hand superfamily. This finding is the first report of the presence of an S-100 protein in vertebrate eggs. Loach $10 \mathrm{kDa}$ shares the highest degree of sequence identity with $\mathrm{S}-100 \alpha$, a protein originally isolated from bovine brain (Moore, 1965). S-100 proteins purified from bovine brain usually contain the $\alpha$ - and $\beta$-subunits in both homo- and heterodimeric forms (Isobe et al., 1977). 
Within the mammalian S-100 family (Fig. 3) S-100 $\alpha$ and $S-100 \beta$ show the highest sequence homology with $57 \%$ identically placed amino acid residues. Since the primary structures of bovine $\mathrm{S}-100 \alpha$ and the loach 10 $\mathrm{kDa}$ protein are even more related (68\% sequence identity) it seems that the $10 \mathrm{kDa}$ protein is the fish homologue of mammalian S-100 $\alpha$. However, with the information currently available we cannot rule out the possibility that the S-100 protein identified in loach eggs is a new member of the $\$ 100$ family particularly closely related to $S-100 \alpha$.

Our fractionation scheme selectively enriches for S-100 proteins, which interact in a $\mathrm{Ca}^{2+}$-dependent manner with hydrophobic matrices. Since the peptide analysis of the $10 \mathrm{kDa}$ band eluted from the phenylSepharose column yielded a unique sequence, it seems very likely that the unfertilized loach eggs contain only one S-100-like protein, the S-100 $\alpha$ homologue. Interestingly, this unique $\mathrm{S}-100$ protein is present in considerable amounts in the unfertilized eggs. Forty ml of egg cytoplasm contain at least $1.5 \mathrm{mg} \mathrm{S}-100 \alpha$, approximately twice as much as calmodulin. The presence of high levels of maternally derived S-100 $\alpha$ in the unfertilized egg argues against a distinct enzymatic function of the protein, which would only require minute amounts. More likely, the protein could function as a $\mathrm{Ca}^{2+}$-buffer or could be involved in mediating $\mathrm{Ca}^{2+}$ signals (e.g. upon fertilization) by binding to other proteins in a $\mathrm{Ca}^{2+}$-dependent manner. Since the affinity of the C-terminal $\mathrm{Ca}^{2+}$-binding site in $\mathrm{S}-100 \alpha$ is in the micromolar range it seems likely that this site becomes occupied during the transient increase of cytosolic $\mathrm{Ca}^{2+}$ levels occurring upon fertilization. Similarly, calmodulin, the other protein of the EF-band superfamily present in loach eggs, will respond to the $\mathrm{Ca}^{2+}$ waves which are thought to trigger cortical granule exocytosis and cell cycle resumption at fertilization. While calmodulin is known to act as a $\mathrm{Ca}^{2+}$-dependent regulator of several enzymes which might be involved in the signal transduction cascade (for review see Klee and Vanaman, 1982) cellular targets for the loach S-100 $\alpha$ have not been identified so far. Protein-protein interactions that are thought to be of functional importance have however been described for other S-100 proteins, e.g. the $\mathrm{Ca}^{2+}$-dependent binding of S-100 to cytoskeleton associated proteins and the glycolytic enzyme aldolase or the interactions of calcyclin with glyceraldehyde-3-phosphate dehydrogenase and the $\mathrm{Ca}^{2+}$ /phospholipid-binding protein CAP-50 which occur in the presence of $\mathrm{Ca}^{2+}$ (see Introduction for references). In the case of $\mathrm{p} 11$, which has lost the ability to bind $\mathrm{Ca}^{2+}$ and interacts in a $\mathrm{Ca}^{2+}$-independent manner with annexin II, the site of protein-protein interaction has been mapped to a hydrophobic region in the C-terminal extension following the second EF-hand (Johnsson and Weber, 1990; Kube et al.,
1992). The corresponding region in S-100 $\alpha$ (residues 88-90) also contains a stretch of hydrophobic residues which are conserved between the mammalian and the fish proteins (see Fig. 3). Since this region in S-100 molecules becomes more accessible to the solvent in the presence of $\mathrm{Ca}^{2+}$ (Mani and Kay, 1983; Baudier and Gerard, 1983; Becker et al., 1992) it could serve as the binding site for a yet to be identified protein ligand of $\mathrm{S}-100 \alpha$.

The unfertilized loach eggs represent a homogenous cell population. In contrast to many tissues which often express a whole set of different S-100 proteins, the eggs seem to contain only a single member of this protein family, S-100 $\alpha$. Since the purification protocol employed to isolate loach $S-100 \alpha$ follows protocols developed for the enrichment of mammalian S-100 proteins, it seems unlikely that a second type of S-100 protein is present in higher amounts in loach eggs but has escaped our attention. Thus S-100 $\alpha$ is probably the only member of the family which is required during early embryonic development.

Although the maternally derived S-100 $\alpha$ is an abundant component in the unfertilized egg and in early embryos, de novo synthesis of this protein is not observed before mid-gastrula stage. The de novo protein synthesis of S-100 $\alpha$ could create regional or cell-type specific differences in the $\mathrm{S}-100 \alpha$ concentration. Interestingly, no other S-100 protein is synthesized during early embryonic development. In embryos prior to gastrulation, the $\mathrm{Ca}^{2+}$-dependent affinity chromatography, a method usually employed to enrich for S-100-like proteins, does not lead to the isolation of any ${ }^{35} \mathrm{~S}$ labelled band with an apparent molecular mass typical of S-100 protein, i.e. $10 \mathrm{kDa}$. This finding also supports the view that $\mathrm{S}-100 \alpha$ but no other member of this protein family is involved in processes of early embryonic development and early cellular differentiation. In contrast to $\mathrm{S}-100 \alpha$, calmodulin is newly synthesized in each developmental stage analyzed. Thus, differences in the local calmodulin concentration can already be expected in very early embryos. This finding is in line with the role of calmodulin as a multifunctional regulator involved in a variety of cellular processes which can occur at a different rate or to a different extent in the cells of the early embryo.

\section{Experimental Procedures}

Fish, eggs and embryos

The loach (Misgurnus fossilis L.) were caught in natural ponds in Russia and kept at $4^{\circ} \mathrm{C}$ for several months without feeding. Loach eggs were obtained and artificially fertilized as described (Neyfakh, 1959). Briefly, maturation of eggs was stimulated by injecting the females with chorionic gonadotropic hormone. Eggs were fertilized by adding a suspension of testis, and 
cultivated in dechlorinated tap water at $21^{\circ} \mathrm{C}$. The embryos reached mid-blastula stage $6.5 \mathrm{~h}$ and midgastrula $14 \mathrm{~h}$ after fertilization. Hatching of the larvae occurred after $50 \mathrm{~h}$.

To remove the fertilization membrane at stages preceding hatching, the embryos were processed through a special pipette equipped with a razor blade knife as described (Lutsik et al., 1983). Subsequently the embryos were separated from the yolk. This procedure is important because (1) the separated embryos are able to absorb amino acids from the medium through the surface which faced the yolk in intact embryos, and (2) yolk proteins account for about $90 \%$ of the total egg protein. Thus the removal of the yolk leads to a significant enrichment of cytoplasmic proteins in the specimen. At blastula and gastrula stages, yolk was removed by placing the embryos in buffer A $(5 \mathrm{mM}$ Tris- $\mathrm{HCl}$, pH 7.5, $120 \mathrm{mM} \mathrm{NaCl}, 1 \mathrm{mM} \mathrm{KCl}, 1 \mathrm{mM} \mathrm{CaCl}$ ) and passing them through a gauze sieve $(0.5 \mathrm{~mm}$ cell). Mid-blastula ( $6.5 \mathrm{~h}$ after fertilization) was the earliest stage when it was possible to separate embryos from the yolk without destroying them. At the stages after gastrulation, yolk was removed by centrifugation of the embryos in a sucrose gradient (Kostomarova and Neyfakh, 1964).

The cytoplasm from unfertilized eggs was obtained by centrifugation of eggs at $5000 \times g$ for $30 \mathrm{~min}$. Under these conditions the eggs are ruptured and the cytoplasm was separated from yolk granules as a deepbrown layer. Roughly $1 \mathrm{ml}$ of cytoplasm was obtained from $10 \mathrm{ml}$ of eggs.

\section{Purification of the $10 \mathrm{kDa}$ protein and calmodulin from loach eggs}

Forty $\mathrm{ml}$ of egg cytoplasm were homogenized by hand in $360 \mathrm{ml}$ of buffer $\mathrm{B}(25 \mathrm{mM}$ Tris- $\mathrm{HCl}, \mathrm{pH} 7.5$, $150 \mathrm{mM} \mathrm{NaCl}, 1 \mathrm{mM}$ DTT, $0.25 \mathrm{mM}$ PMSF) using a glass/Teflon homogenizer. $\mathrm{CaCl}_{2}$ was added to 10 $\mathrm{mM}$ and the mixture was kept on ice for $30 \mathrm{~min}$. After centrifugation at $100,000 \times g$ for $45 \mathrm{~min}$ the supernatant was applied to a phenyl-Sepharose (Pharmacia) column $(40 \mathrm{ml})$ equilibrated in buffer B containing 10 $\mathrm{mM} \mathrm{CaCl}{ }_{2}$. Subsequently the column was washed with $4 \mathrm{l}$ of buffer $\mathrm{B}$ containing $0.1 \mathrm{mM} \mathrm{CaCl} \mathrm{Ca}_{2}$ and then eluted with $120 \mathrm{ml}$ of buffer $B$ containing $1 \mathrm{mM}$ EGTA. The eluate was adjusted to a final concentration of $10 \mathrm{mM} \mathrm{CaCl}_{2}$ and applied to a second phenylSepharose column $(2 \mathrm{ml})$ equilibrated in buffer $\mathrm{B}$ containing $10 \mathrm{mM} \mathrm{CaCl}_{2}$. The column was washed with 10 $\mathrm{ml}$ of buffer $\mathrm{B}$ containing $0.1 \mathrm{mM} \mathrm{CaCl}$ and eluted with $6 \mathrm{ml}$ of buffer $B$ containing $1 \mathrm{mM}$ EGTA. Phenyl-Sepharose chromatography was performed at room temperature. The final eluate was diluted 3-fold with distilled water and applied to a DEAE-Sepharose (Pharmacia) column $(0.4 \times 8 \mathrm{~cm})$ equilibrated in buffer C (10 mM Tris-HCl, pH 7.5, $1 \mathrm{mM}$ DTT, $1 \mathrm{mM}$
EGTA) containing $50 \mathrm{mM} \mathrm{NaCl}$. The column was washed with $5 \mathrm{ml}$ of buffer $\mathrm{C}$ containing $50 \mathrm{mM} \mathrm{NaCl}$ and eluted with a linear salt gradient $(20 \mathrm{ml} ; 0.1-0.4 \mathrm{M}$ $\mathrm{NaCl}$ in buffer $\mathrm{C}$ ). The fractions were analyzed in SDS $16 \%$ polyacrylamide gels using the tricine buffer system (Schägger and von Jagow, 1987). The $10 \mathrm{kDa} \mathrm{Ca}^{2+}$-binding protein eluted at $0.2-0.25 \mathrm{M} \mathrm{NaCl}$ and calmodulin eluted at $0.3-0.35 \mathrm{M} \mathrm{NaCl}$. Peak fractions containing the pure proteins were dialyzed against $0.1 \mathrm{M}$ $\mathrm{NH}_{4} \mathrm{HCO}_{3}$ using benzoylated dialysis tubing (Sigma) with reduced pore size and lyophilized. Protein concentrations were determined by the method of Bradford (1976) using BSA as a standard. About $1.5 \mathrm{mg}$ of $10 \mathrm{kDa}$ and $0.8 \mathrm{mg}$ of calmodulin were obtained from $40 \mathrm{ml}$ of egg cytoplasm.

\section{Protein-chemical procedures}

After $\mathrm{CNBr}$ treatment of the purified proteins by standard procedures, separation of fragments was by HPLC. Automated gas phase sequencing used either an Applied Biosystems Sequenator (model 470A) or a Knauer sequenator (model 810). Both instruments were equipped with an online phenylthiohydantoin-amino acid analyzer. The $10 \mathrm{kDa}$ protein was also blotted from SDS polyacrylamide gels on a polyvinyldifluoride membrane (Bauw et al., 1989) and either directly sequenced or treated in situ with endoproteinase Asp-N (Boehringer-Mannheim, Germany) for 4 hours at $37^{\circ} \mathrm{C}$. Peptides released from the blot were subjected to HPLC and sequenced.

Isotopic labelling of loach embryos and fluorographic analysis of the $10 \mathrm{kDa}$ and calmodulin expression

Embryos were separated from the yolk and then allowed to settle. About $1 \mathrm{ml}$ of settled embryos were washed with buffer A adjusted to $0.1 \mathrm{M}$ Tris- $\mathrm{HCl}, \mathrm{pH}$ 7.5 and incubated in a minimal volume of the medium containing $0.25 \mathrm{mCi}\left[{ }^{35} \mathrm{~S}\right.$ ]methionine (Radiopreparat, USSR) for $75 \mathrm{~min}$ at $21^{\circ} \mathrm{C}$. The swimming larvae deprived of residual yolk were labelled for $3 \mathrm{~h}$ because of weak absorption of $\left[{ }^{35} \mathrm{~S}\right]$ methionine from the medium. Labelling was stopped by freezing of embryos or larvae at $-70^{\circ} \mathrm{C}$. The $10 \mathrm{kDa}$ protein and calmodulin were purified from the labelled embryos by phenyl-Sepharose chromatography as described above and analyzed in tricine-SDS-16\% polyacrylamide gels. The gels were stained with Coomassie blue, photographed and then processed for fluorography (Bonner and Laskey, 1974) and exposed to X-ray film RM-1 (Tasma, USSR) at $-70^{\circ} \mathrm{C}$.

\section{Acknowledgement}

This study was supported by a fellowship (to V.V.I.) from the Bundesministerium für Forschung und Technologie (BMFT). 


\section{References}

Babu, Y.S., Sack, J.S., Greenhough, T.J., Bugg, C.E., Means, A.R. and Cook, W.J. (1985) Nature 315, 37-40.

Baudier, J. and Cole, R.D. (1988) Biochemistry 27, 2728-2736.

Baudier, J. and Gérard, D. (1983) Biochemistry 22, 3360-3369.

Bauw, G., van Damme, J., Puype, M., Vandekerckhove, J., Gesser, B., Ratz, G.P., Lauridsen, J.B. and Celis, J.E. (1989) Proc. Natl. Acad. Sci. USA 86, 7701-7705.

Becker, T., Gerke, V., Kube, E. and Weber, K. (1992) Eur. J. Biochem. 207, 541-547.

Bement, W.M. and Capco, D.G. (1989) J. Cell Biol. 108, 885-892.

Bonner, W.M. and Laskey, R.A. (1974) Eur. J. Biochem. 46, 83-88. Bradford, M.M. (1976) Anal. Biochem. 72, 248-254.

Calabretta, B., Battini, R., Kaczmarek, L., de Riel, J.K. and Baserga, R. (1986) J. Biol. Chem. 261, 12628-12632.

Ciapa, B., Crossley, I. and DeRenzis, G.D. (1988) Dev. Biol. 128, $142-149$.

Davis, T.N., Urdea, M.S., Masiarz, F.R. and Thorner, J. (1986) Cell 47, 423-431.

Donato, R. (1991) Cell Calcium 12, 713-726.

Drust, D.S. and Creutz, C.E. (1988) Nature 331, 88-91.

Endo, Y., Schultz, R.M. and Kopf, G.S. (1987). Dev. Biol. 119 , 199-209.

Filipek, A., Gerke, V., Weber, K. and Kuznicki, J. (1991) Eur. J. Biochem. 195, 795-800.

Fischer, R., Koller, M., Flura, M., Mathews, S. Strehler-Page, M.A., Krebs, J., Penniston, J.T., Carafoli, E. and Strehler, E.E. (1988) J. Biol. Chem. 263, 17055-17062.

Fujii, T., Machino, K., Andoh, H., Satoh, T. and Konodo, Y. (1990) J. Biochem. (Tokyo) 107, 133-137.

Gerke, V. and Weber, K. (1984) EMBO J. 3, 227-223.

Gerke, V. and Weber, K. (1985a) EMBO J. 4, 2917-2920.

Gerke, V. and Weber, K. (1985b) J. Biol. Chem. 260, 1688-1695.

Gilkey, J.C., Jaffe, L.F., Ridgway, E.B. and Reynolds, G.T. (1978) J. Cell Biol. 76, 448-466.

Gilkey, J.C. (1983) J. Cell Biol, 97, 669-678.

Glenney, J.R., Jr. (1986) J. Biol. Chem. 261, 7247-7252.

Glenney, J.R., Jr., Kindy, M.S. and Zokas, L. (1989) J. Cell Biol. 108, 569-578.

Hilt, D.C. and Kligman, D. (1991) in: Novel Calcium-Binding Proteins. Heizmann, C.W. (ed.), Springer Verlag, Berlin, pp. 65-103.

Hiramoto, Y., Yoshimoto, Y. and Iwamatsu, T. (1989) Acta Histochem. Cytochem. 22, 153-156.

Isobe, T., Nakajima, T. and Okujama, T. (1977) Biochim. Biophys. Acta 494, 222-232.

Isobe, T. and Okujama, T. (1978) Eur. J. Biochem. 89, 379-388.
Isobe, T.,and Okujama, T. (1981) Eur. J. Biochem. 116, 79-86.

Iwamatsu, T., Yoshimoto, Y. and Hiramoto, Y. (1988) Dev. Biol. 125 , 451-457.

Jaffe, L.F. (1985) in: Biology of Fertilization. Metz, C.B. and Monroy, A. (eds.), Academic Press, New York, pp. 127-165.

Johnson, N. and Weber, K. (1990) J. Biol. Chem. 265, 14464-14468.

Klee, C.B., Crouch, T.H. and Richman, P.G. (1980) Annu. Rev. Biochem. 49, 489-515.

Klee, C.B. and Vanaman, T.C. (1982) Adv. Protein Chem. 35, 213-321.

Kostomarova, A.A. and Neyfakh, A.A. (1964) Zh. Obsch. Biol. (Russia) 25, 386-388.

Kretsinger, R.H. (1980) CRC Crit. Rev. Biochem. 8, 119-174.

Kretsinger, R.H. (1987) Cold Spring Harbor Symp. Quant. Biol. 52, $499-510$.

Kube, E., Weber, K. and Gerke, V. (1991) Gene 102, 255-259.

Kube, E., Becker, T., Weber, K. and Gerke, V. (1992) J. Biol. Chem. 267, 14175-14182.

Lutsik, M.D., Lukyanenko, A.V. and Kusen, S.J. (1983) Ontogenesis 14, 642-645.

Mani, R.S. and Kay, C.M. (1983) FEBS Lett. 163, 282-286.

Marshak, D.R., Clarke, M., Roberts, D.M. and Watterson, D.M. (1984) Biochemistry 23, 2891-2899.

Moore, B. (1965) Biochem. Biophys. Res. Commun. 19, 739-744.

Neyfakh, A.A. (1959) J. Gen. Biol. (Russia) 20, 202-213.

Ohta, H., Sasaki, T., Naka, M., Hiraoka, O., Miyamoto, C., Furuichi, Y. and Tanaka, T. (1991) FEBS Lett. 295, 93-96.

Osborn, M., Johnsson, N., Wehland, J. and Weber, K. (1988) Exp. Cell Res. 175, 81-96.

Persechini, A., Moncrief, N.D. and Kretsinger, R.H. (1989) Trends Neurosci. 12, 462-467.

Powell, M.A. and Glenney, J.R., Jr. (1987) Biochem. J. 247, 321-328.

Saris, C.J.M., Kristensen, T., D'Eustachio, P. Hicks, L.I., Noonan, D.J., Hunter, T. and Tack, B.F. (1987) J. Biol. Chem. 262, 10663-10671.

Schägger, H. and von Jagow, O. (1987) Anal. Biochem. 166, 368-379.

Schuel, H. (1985) in: Biology of Fertilization, vol. 3. Metz, C.B. and Monroy, A. (eds.), Academic Press, New York, pp. 1-43.

Tokumitsu, H., Mizutani, A. Minami, H., Kobayashi, R. and Hidaka, H. (1992) J. Biol. Chem. 267, 8919-8924.

Watanabe, M., Ando, Y., Todoroki, H., Minami, H. and Hidaka, H. (1991) Biochem. Biophys. Res. Commun. 181, 644-649.

Whitaker, M. and Patel, R. (1990) Development 108, 525-542.

Zimmer, D.B. and Van Eldik, L.J. (1986) J. Biol. Chem. 261, 1142411428.

Yoshimoto, Y., Iwamatsu, T., Hirano, K.I. and Hiramoto, Y. (1986) Dev. Growth Differ. 28, 583-596. 